Available online at GSC Online Press Directory

GSC Biological and Pharmaceutical Sciences

e-ISSN: 2581-3250, CODEN (USA): GBPSC2

Journal homepage: https://www.gsconlinepress.com/journals/gscbps

(RESEARCH ARTICLE)

\title{
Safety and health benefits profile studies of leaf extracts of Momordica balsamina Linn (Cucurbitaceae) found in North Central Nigeria
}

\author{
Kadiri Okai Jonathan *, Okafor Sylvester Ignatius and Ogaji Joshua Ikoni \\ Department of Pharmaceutical Technology and Industrial Pharmacy, Faculty of Pharmaceutical Sciences, University of \\ Jos, Jos, Nigeria.
}

Publication history: Received on 12 February 2020; revised on 22 May 2020; accepted on 26 May 2020

Article DOI: https://doi.org/10.30574/gscbps.2020.11.2.0039

\begin{abstract}
Momordica balsamina Linn (Cucurbitaceae) plant possesses both medicinal and nutritional properties and has been used for its nutritional and medicinal benefits. The purpose of this paper was to evaluate the safety and health benefits of the leaf extracts of the plant found in North Central Nigeria. The leaf powder was sequentially extracted with solvents of varying polarity index. The protein and amino acid contents were determined by micro Kjeldahl nitrogen methods. The lipid, carbohydrate, fibre and ash contents were determined by well-established and standardized methods. The mineral compositions were analyzed by atomic absorption spectrophotometer. The antioxidant activity was evaluated by the scavenging activity of the extracts on DPPH free radical, while the acute toxicity studies were carried out using male albino rats. Results show that the leaf contains $22 \pm 0.58 \%$ of crude proteins on dry weight basis. The corresponding values for carbohydrates, lipids, crude fibre and ash are $32.5 \pm 0.8,3.98 \pm 0.12,16.72 \pm 1$ and $21 \pm 0.81 \%$ respectively. The calorific value and moisture content are $201.23 \mathrm{Kcal} / 100 \mathrm{~g}$ and $3.77 \pm 0.22 \%$ respectively. The leaf was composed of macro- and micro nutrients. The methanolic extract possesses the highest radical scavenging activity. The median lethal dose of the aqueous extract at $5000 \mathrm{mg} / \mathrm{kg}$ body weight showed no mortality. These results indicate that the leaf of Momordica balsamina possesses nutritional and antioxidant properties, and is safe for consumption as herbal vegetable.
\end{abstract}

Keywords: Momordica balsamina; Composition; Radical scavenging; Safety; Health

\section{Introduction}

There is a growing interest in the use of herbs as food and medicines [1]. Some herbs such as Bidens pilosa serve as vegetable or remedy for diabetes and cancer [2]. Plants such as Moringa oleifera serve as herbs and are eaten as vegetable for nutritional needs or as a remedy for hepatitis, cardiovascular disease or cancer [3]. Vernonia amygdalina has antidiabetic, anti-infective, anti-cancer and anti-inflammatory properties [4]. It is important to evaluate the proximate and mineral compositions and the antioxidant properties of herbs and vegetables in order to determine their nutritional values and radical scavenging properties for human health. In a population where the consumption of these herbs and vegetables are not taken seriously, vitamins, macro- and micronutrients deficiencies may cause malnutrition, chronic and terminal diseases such as hypertension, diabetes mellitus, and cancer [5]

Momordica balsamina also known as 'Balsam apple' (African pumpkin), is an important medicinal and nutritional plant of the Cucurbitaceae family. It is an annual or perennial tendril-bearing herb native to tropical regions of Africa. In India, it occurs naturally in forest, in the rainy season. The leaves, fruits, seeds, and bark possess various constituents of medicinal and nutritional importance. It is called 'Hidden gift of Nature' [6]. 'Momordins'or'Balsamin' is reported to inhibit the growth of human immune deficiency virus (HIV) and other viruses [6, 7]. The leaf and fruit extracts possess antiplasmodial activity and is used against malaria in African traditional medicine [8]. It has been reported that the

\footnotetext{
${ }^{*}$ Corresponding author: Kadiri Okai Jonathan
} 
extracts from parts of this plant possess shigellocidal, anti-diarrhoeal, antiseptic, anti-inflammatory, hypoglycemic and antimicrobial properties $[9,10,11]$. The purpose of this work was to evaluate the proximate and mineral compositions, free radical scavenging activity and acute toxicity of the leaf extracts of this plant. The work would highlight the nutritional values of the plant.

\section{Material and methods}

\subsection{Materials}

Momordica balsamina leaves were collected from Jos North area of Plateau State, Nigeria. The identification and authentication was done at the Federal College of Forestry, Jos, Plateau State, where voucher number 288 was deposited. The animals used were purchased from the Animal House of the University of Jos. Other materials used in the work were of analytical grade.

\subsection{Methods}

\subsubsection{Preparation and Extraction of Momordica balsamina Leaves}

The methods adopted for the extraction of constituents of the leaves of this plant have been reported previously [12].The leaf powder was sequentially extracted with hexane, dichloromethane, acetone, methanol and distilled water in order of increasing polarity index. The extracts were filtered using Whatman No. 1 filter paper. Evaporation of solvent from the extract was carried out at $40{ }^{\circ} \mathrm{C}$ using rotary evaporator (Model RE 100, England). Subsequent extractions were carried out using the same procedure.

\subsubsection{Moisture content determination}

A $2.5 \mathrm{~g}$ of size- reduced dry Momordica leaf was weighed into a dry silica dish of known weight. The dish and its contents were placed in a hot air oven at $60^{\circ} \mathrm{C}$ for $1 \mathrm{~h}$, and cooled in a desiccator for $10 \mathrm{~min}$. The procedure was repeated until a constant weight was achieved. The moisture content was calculated according to the formula:

$\%$ Moisture $=\frac{W_{1}-W_{2}}{W_{1}} \times 100$

Where $W_{1}=$ Weight of Momordica leaf before drying and $W_{2}=$ Weight of Momordica leaf after drying.

\subsubsection{Micro Kjeldahl nitrogen (crude protein) determination}

A 2 g size-reduced sample of M. balsamina leaf was placed in Kjeldahl flask. Then 200 mg of catalyst mixture (copper and titanium sulphate) and $2 \mathrm{~g}$ of sodium sulphate were added. A $10 \mathrm{ml}$ quantity of concentrated sulphuric acid was added to the contents of the flask and heated gently for a few minutes until frothing ceased. The heat was increased and the sample digested for $3 \mathrm{~h}$, cooled and the volume made up to $100 \mathrm{ml}$ with distilled water. A 10 ml aliquot was pipetted into the chamber of micro Kjeldahl distillation apparatus, and $10 \mathrm{ml}$ of $40 \%$ sodium hydroxide solution was added. The ammonia produced was distilled into $10 \mathrm{ml}$ of $2 \%$ boric acid containing mixed indicator. The excess ammonia was neutralized by titration with $0.1 \mathrm{~N}$ hydrochloric acid which produced a grey colour as the end point. The percentage nitrogen content of the sample was calculated according to the formula:

$\% N=\frac{(a-b) \times 0.01 \times 14.0057 \times c}{d \times e} \times 100$

Where $\mathrm{a}=$ titre value of the sample, $\mathrm{b}=$ titre value of the blank, $\mathrm{c}=$ dilution factor, $\mathrm{d}=$ aliquot taken for distillation, $\mathrm{e}$ $=$ weight of dried sample $(\mathrm{mg})$. The percentage crude protein was obtained by multiplying the percentage nitrogen by 6.25 .

\subsubsection{Ash determination}

The residue $\left(1.5 \mathrm{~g}\right.$ ) from the moisture content determination was charred in a muffle furnace at $500{ }^{\circ} \mathrm{C}$ for $12 \mathrm{~h}$. The grey ash produced was cooled and weighed. 


\subsubsection{Fat determination (ether-extract)}

A Soxhlet extractor fitted with a reflux condenser and a small flask which was previously dried in the oven and weighed was used. A $2 \mathrm{~g}$ of sample of the ether extract (oil) was weighed and transferred to a fat-free extraction thimble, and plugged lightly with cotton wool. The thimble was placed in a $100 \mathrm{ml}$ extractor. Then $150 \mathrm{ml}$ of petroleum ether (boiling point $60-80^{\circ} \mathrm{C}$ ) was added until it siphons over. More ether was added until the barrel of the $100 \mathrm{ml}$ extractor was half full. The extraction was allowed to proceed gently for $8 \mathrm{~h}$. When the ether was just short of siphoning over, the flask was detached and the contents were siphoned into the ether stock bottle. After draining, the thimble was removed and dried in the oven. The condenser was replaced and distillation continued until the ether in the flask was practically dry. The flask containing the extracted oil was detached; the exterior was cleaned and dried in the oven to constant weight. The percentage ether extract was calculated as follows:

$$
\text { Ether extract }=\frac{\text { Weight of oil }}{\text { Weight of sample }} \times 100
$$

\subsubsection{Crude fibre determination}

The trichloroacetic acid (TCA) method for crude fibre determination was used. A $20 \mathrm{~g}$ of trichloroacetic acid was dissolved in a mixture consisting of $500 \mathrm{ml}$ glacial acetic acid, $450 \mathrm{ml}$ water and $50 \mathrm{ml}$ concentrated nitric acid. A $1 \mathrm{~g}$ quantity of the defatted M. balsamina leaf was weighed into a $250 \mathrm{ml}$ conical flask. Then $100 \mathrm{ml}$ of the TCA mixture was transferred into the flask and refluxed for $40 \mathrm{~min}$. The flask was disconnected and allowed to cool. The material was filtered through a $15 \mathrm{~cm}$ Whatman No 4 filter paper previously dried and weighed. It was washed 10 times with hot distilled water, and once with industrial absolute ethanol and dried in an oven at $105^{\circ} \mathrm{C}$ for $12 \mathrm{~h}$. The dried material was transferred to a desiccator and weighed after cooling. The filter paper and the residue were transferred into a previously weighed crucible and heated at $500^{\circ} \mathrm{C}$ for $12 \mathrm{~h}$. The percentage crude fibre was calculated.

\subsubsection{Determination of amino acid profile}

The amino acid profile of the leaf powder was determined using the method reported by Ekeanyanwu [13]. A $3 \mathrm{~g}$ quantity of the dried sample was defatted using chloroform/methanol mixture in the ratio of 2:1 in a Soxhlet extractor. A $300 \mathrm{mg}$ weight of the defatted sample was weighed into a glass ampoule. Then $7 \mathrm{ml}$ of $6 \mathrm{~N}$ hydrochloric acid (HCl) was added. Oxygen was expelled by bubbling nitrogen into the ampoule. The sealed ampoule was heated in an oven at $105 \pm$ $50 \mathrm{C}$ for $22 \mathrm{~h}$, cooled and the contents filtered to remove the humins. The filtrate was evaporated to dryness. The residue

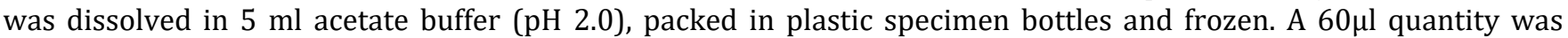
dispensed into the cartridge of an amino acid analyser (Applied Biosystems PTH Amino Acid Analyzer, Model 120 A, USA) designed to separate and analyze acidic, neutral and basic amino acids of the hydrolysate. The energy value of $M$. balsamina leaf was estimated in calories (kcal) using Atwater Specific Factors for Selected Foods Table [14].

\subsubsection{Quantitative determination of tryptophan}

A $300 \mathrm{mg}$ sample was dried to constant weight, defatted, and hydrolyzed with $4.2 \mathrm{M}$ Sodium hydroxide [15]. The hydrolysed sample was evaporated in a rotary evaporator and loaded into the Applied Biosystems PTH Amino Acid AnalyzerPTH (Model 120 A, USA).

\subsubsection{Mineral composition}

A $2 \mathrm{~g}$ quantity of the powdered sample contained in a crucible was digested in $30 \mathrm{ml}$ of concentrated nitric acid on a hot plate placed inside a fume cupboard until digestion was complete. The digested sample was diluted with $50 \mathrm{ml}$ of warm distilled water and filtered into a $100 \mathrm{ml}$ volumetric flask. The metallic elements of the filtrate were analyzed using Atomic Absorption Spectrometer (AAS) (Thermo Scientific ICE 3000 series, USA). The extracts were prepared in sterile water as 5,10 and $20 \mathrm{mg} / \mathrm{ml}$ respectively.

\subsubsection{DPPH radical scavenging activity}

The antioxidant activity of the extracts on the stable radical, 1,1-diphenyl-2-picrylhydrazyl (DPPH) was determined according to the method reported by Brand-Williams [16]. Dichloromethane, methanol, acetone and aqueous extracts of plant material in concentrations of $0.98-500 \mu \mathrm{g} / \mathrm{ml}$ in methanol were prepared. A 2 ml quantity of the methanolic dispersion of each extract was mixed with $4 \mathrm{ml}$ of $50 \mu \mathrm{M} / \mathrm{ml} \mathrm{DPPH}$ solution in methanol. The mixture contained in test tubes was vortexed for $10 \mathrm{~s}$ and incubated for $30 \mathrm{~min}$ at room temperature of $28^{\circ} \mathrm{C}$ in the dark. The absorbance of the supernatant was measured at $515 \mathrm{~nm}$ using UV-Vis spectrophotometer (Shimadzu, 1620 Japan). Low absorbance value indicates high free radical scavenging activity. Ascorbic acid was used as standard in concentrations of $0.195-100$ 
$\mu \mathrm{M} / \mathrm{ml}$ in methanol. A blank solution was prepared by mixing $2 \mathrm{ml}$ of methanol with $4 \mathrm{ml}$ of $50 \mu \mathrm{M} / \mathrm{ml} \mathrm{DPPH}$ solution in ethanol. The differences in the absorbance values of the test samples and control (DPPH in methanol) were calculated and expressed as the percentage of scavenging of DPPH radical. The capability to scavenge the DPPH radical was calculated by using the following equation:

$$
\% \text { inhibition }=\frac{\text { Absorbance of control }- \text { Absorbance of sample }}{\text { Absorbance of control }} \times 100 \ldots \ldots \ldots \text { (4) }
$$

Finally, the $\mathrm{IC}_{50}$ value, defined as the concentration of the sample causing a $50 \%$ reduction of the initial DPPH concentration, was calculated from the separate linear regression plots of the mean percentage of the antioxidant activity against concentration of the test extract $(\mu \mathrm{g} / \mathrm{ml})$.

\subsubsection{Acute toxicity test}

The Lorke's acute toxicity test method reported by Deora, [17] and Parasuraman, [18] was adopted with slight modification. Eighteen (18) male albino rats (117.3 - $180 \mathrm{~g}$ ) were used, after obtaining approval from the Animal Ethics Committee of the Faculty of Pharmaceutical Sciences, University of Jos. In the first phase of the tests, the animals were grouped in 3's according to their body weight, kept in cages and given standard food and water ad libitum for a week. Group I (131.5 $\pm 5.26 \mathrm{~g})$, II (140 g), and III (145.6 $\pm 2.3 \mathrm{~g}$ ) were administered 10,100 , and $1000 \mathrm{mg} / \mathrm{kg}$ body weight of the water extract orally respectively after overnight starving. The animals were closely monitored within the first $24 \mathrm{~h}$ and daily for 2 weeks. In the absence of death from the groups, the second phase of nine rats [Group I (167 \pm 12 ), II (142 \pm 5.3 ), and III (129.16 \pm 10$)]$ were administered orally 1600, 2900 and $5000 \mathrm{mg} / \mathrm{kg}$ body weight of the water extract respectively and observed as described above. The median lethal dose (LD50) was calculated as the geometric mean of the least dose that produced mortality, and the highest dose that produced no mortality.

\section{Results and discussion}

\subsection{Nutritional properties}

The hexane extract was oily and yellowish in colour. Those of dichloromethane, acetone and methanol were greenish in colour and sticky. The water extract was dark brown in colour and hygroscopic. Table1shows that the moisture content of Momordica balsamina dried leaves was $3.77 \pm 0.22 \%$. Low moisture content of vegetable drugs minimizes microbial and chemical degradation of the constituents. The crude protein content was $22 \pm 0.58 \%$. This is higher than the 11.29 $\%$ reported by Hassan and Umar [10] for leaves of the same plant collected from Kebbi State, Nigeria. Plants that possess more than $12 \%$ of crude protein are considered as good source of protein [10]. The high protein content of M. balsamina makes it useful in managing malnutrition among indigent communities in Africa. The percentage ash content was $21 \pm$ $0.81 \%$. Ash content is an index of the mineral composition. The crude lipid content is $3.98 \pm 0.12 \%$ DW. This is lower than the $5.4 \%$ reported by Flyman and Afolayan [19], but higher than the $2.66 \%$ reported by Hassan \& Umar [10] for M. balsamina obtained from Botswana and Jega community in South Africa and Nigeria respectively. The result indicates that M. balsamina leaf is poor in lipid content. This is advantageous in the management of obesity and cardiovascular diseases. The carbohydrate content is $32.5 \pm 0.8 \% \mathrm{DW}$. Although this value did not meet the recommended dietary allowance (RDA) of $130 \mathrm{~g}$ in children and adults; $175 \mathrm{~g}$ in pregnant women; and $210 \mathrm{~g}$ in lactating mothers [10], it is suitable for people who need to reduce their intake of calories, especially in the management of obesity and other cardiovascular diseases.

Table 1 Per cent Proximate Composition of Momordica balsamina Leaf (Dry matter)

\begin{tabular}{lllllll}
\hline $\begin{array}{l}\text { Crude } \\
\text { protein }\end{array}$ & Carbohydrate & $\begin{array}{l}\text { Ether } \\
\text { extract }\end{array}$ & $\begin{array}{l}\text { Crude } \\
\text { fiber }\end{array}$ & Moisture & Ash & $\begin{array}{l}\text { Calorific value } \\
\text { (Kcal/100 g) }\end{array}$ \\
\hline $22 \pm 0.58$ & $32.5 \pm 0.8$ & $3.98 \pm 0.12$ & $16.72 \pm 1$ & $3.77 \pm 0.22$ & $21 \pm 0.81$ & 201.23 \\
\hline
\end{tabular}

The crude fibre content of the sample was $16.72 \pm 1 \% \mathrm{DW}$. This is higher than the $5.4 \%$ obtained for M. balsamina from Botswana [19], but lower than the $29 \%$ obtained from Jega community, Nigeria. Dietary fibre may reduce the risk of coronary heart disease (CHD) by improving blood lipid and glucose profiles, lowering blood pressure, and improving 
insulin sensitivity and fibrinolytic activity $[10,20]$. The RDA values of crude fibre for children, adult, pregnant and lactating mothers are $19-25,21-38,28$ and $29 \%$ respectively [10]. M. balsamina leaves can serve as a source of dietary fibre in human nutrition. The calorific value of $201.23 \mathrm{kcal} / 100 \mathrm{~g}$ (DW) obtained from the sample is higher than the189.22 Kcal/ $100 \mathrm{~g} \mathrm{DW}$ reported for that obtained from Jega community in Nigeria. Vegetables are expected to possess low calorific value [10].The percent protein content of the sample was approximately $22 \%$. Table 2 shows the amino acid composition of $M$. balsamina leaf. The essential amino acids constitute $43.8 \%$ of the total amino acids. They include phenylalanine, valine, threonine, tyrosine, isoleucine, methionine, cysteine, leucine and lysine. The remaining $56.2 \%$ of amino acids belong to the non-essential amino acids comprising proline, arginine, histidine, alanine, glutamic acid, glycine, serine and aspartic acid. The most prominent essential amino acid was leucine (7.94 g), followed by phenylalanine (4.43 g). The most prominent non-essential amino acid was glutamic acid (11.66 g), followed by aspartic acid (8.25 g). These results are similar to those reported by Hassan and Umar [10] for the plant. Methionine is a precursor of cysteine, and cysteine is a precursor of glutathione, a free radical scavenger [21]. The presence of these essential amino acids in M. balsamina leaf may reduce the depletion of glutathione store in the body, thereby contributing to general wellness through this antioxidant effect. Phenylalanine is known for its anti-sickling effect in the management of sickle cell disease [22]. Phenylalanine, tyrosine and tryptophan in medicinal plants have been involved in the management of sickle cell anaemia [22].

Table 2 Amino acid Composition of the Plant Leaf

\begin{tabular}{lc}
\hline Amino acid & Concentration (g/100 g protein) \\
\hline *Leucine & 7.94 \\
*Lysine & 4.03 \\
*Isoleucine & 3.34 \\
*Phenylalanine & 4.43 \\
Tryptophan & 0.94 \\
*Valine & 3.98 \\
*Methionine & 1.12 \\
Proline & 3.25 \\
Arginine & 4.13 \\
*Tyrosine & 3.10 \\
Histidine & 2.17 \\
*Cysteine & 0.97 \\
Alanine & 4.17 \\
Glutamic acid & 11.66 \\
Glycine & 3.99 \\
*Threonine & 3.27 \\
Serine & 3.73 \\
Aspartic acid & 8.25 \\
\hline Esential amino acid &
\end{tabular}

Table 3 shows the mineral contents of the sample. The sample contains $416.86 \mathrm{mg} / \mathrm{l}$ of potassium, $396 \mathrm{mg} / \mathrm{l}$ of calcium, and $97.35 \mathrm{mg} / \mathrm{l}$ of magnesium. These are the major macro elements present. The main micro elements include manganese $(1.97 \mathrm{mg} / \mathrm{l})$, zinc $(0.89 \mathrm{mg} / \mathrm{l})$ and copper $(0.25 \mathrm{mg} / \mathrm{l})$. Macro elements are minerals that are needed by the body in large quantity while trace elements are needed in small quantity. This result is in conformity with those reported for the plant from Jega community in Nigeria [10]. The role of calcium and magnesium in bone and teeth development, muscles function and body metabolic processes cannot be overemphasized. Almost $60 \%$ of magnesium in the body is stored in the bones. Consequently, magnesium deficiency contributes to osteoporosis [23]. Intake of calcium and vitamin D prevents osteoporosis. Calcium and magnesium in diets are very important in bone development and maturity. 
Table 3 Mineral Composition of Momordica balsamina Leaf

\begin{tabular}{ll}
\hline Mineral & Concentration $(\mathbf{m g} / \mathbf{L})$ \\
\hline Magnesium & 97.35 \\
Sodium & 10.25 \\
Potassium & 416.86 \\
Calcium & 396.00 \\
Zinc & 0.89 \\
Manganese & 1.97 \\
Copper & 0.25 \\
Lead & $* \mathrm{Nd}$ \\
\hline \multicolumn{2}{c}{$* \mathrm{Nd}=$ Not detected }
\end{tabular}

The macro- and micronutrients in M. balsamina make it useful when considering herbs for management of mineral deficiencies, and in the management of hypertension and cardiovascular diseases [19]. Minerals play significant role in blood pressure control in the human body. Perez and Chang [24] reported that sodium: potassium ratio is more strongly associated with blood pressure outcomes in adults than sodium or potassium alone. People who consume diets with low-sodium/high potassium ratio have controlled blood pressure compared to those in the opposite group [24]. High consumption of fruits and vegetables in some isolated societies resulted in only $1 \%$ of the population having hypertension, while those in industrialized countries that consume diets high in processed foods and large amount of dietary sodium, 1 out of 3 persons has hypertension [24]. Primitive diets are known to be high in potassium but low in sodium [24]. Houston and Harper [25] reported that low potassium intake in the United States contributed to the prevalence of hypertension in the region. The authors [24, 25] also found that the administration of combinations of magnesium, calcium and potassium in their natural form led to effective reduction of blood pressure (BP). The roles of manganese, zinc and copper in immune functions and diabetes management have been reported [26, 27].

\subsection{Antioxidant properties}

Table 4 shows the antioxidant activity of the extracts. The high concentration of flavonoids in the methanolic extract with IC 50 of $141.90 \pm 16.31 \mu \mathrm{g} / \mathrm{ml}$ is consistent with its high antioxidant activity. The corresponding IC 50 values for dichloromethane, acetone and aqueous extracts were $255.43 \pm 4.41,277.83 \pm 34.05$, and $826.62 \pm 55.97 \mu \mathrm{g} / \mathrm{ml}$ respectively. Ascorbic acid had an $\mathrm{IC}_{50}$ value of $0.397 \mu \mathrm{g} / \mathrm{ml}$. Extracts with $\mathrm{IC}_{50}$ values $\leq 100 \mu \mathrm{g} / \mathrm{ml}$ are active antioxidants, while those with values $\geq 200 \mu \mathrm{g} / \mathrm{ml}$ are not [28]. On the basis of these, the

Table 4 Antioxidant Property of Momordica balsamina leaf Extracts

\begin{tabular}{llcl}
\hline Solvent Extracts & $\begin{array}{c}\text { Total Flavonoid Content } \\
\mathbf{( m g / g )}\end{array}$ & $\begin{array}{c}\text { Total Phenol Content } \\
\mathbf{( m g} / \mathbf{g})\end{array}$ & $\mathbf{I C 5 0}(\boldsymbol{\mu g} / \mathbf{m l})$ \\
\hline Dichloromethane & $142.88 \pm 10.28 *$ & $9.70 \pm 2.35$ & $255.43 \pm 4.41$ \\
Acetone & $122.46 \pm 4.42$ & $4.37 \pm 1.70$ & $277.83 \pm 34.05$ \\
Methanol & $232.46 \pm 33.81$ & $6.14 \pm 0.00$ & $141.90 \pm 16.31$ \\
Water & $3.19 \pm 0.64$ & $9.23 \pm 1.02$ & $826.62 \pm 55.97$ \\
Standard & - & & $0.397 \pm 0.00$ \\
\hline
\end{tabular}

*Mean \pm standard deviation

Methanolic extract possessed fairly active antioxidant activity, while the other extracts did not. Aerobic organisms are exposed to ROS (reactive oxygen species) formation. Antioxidant activity is required in stressful conditions such as pathogen attacks, wounds, herbivore feeding, UV light, heavy metals and others. The antioxidant action of phenolic compounds is due to their high tendency to chelate metals. Phenolics possess hydroxyl and carboxyl groups which are able to bind iron and copper $[29,30,31]$. All the extracts possessed some level of antioxidant capacity because of the presence flavonoids which are phenolic in nature. The antioxidant activity of M. balsamina may be due to the presence of phenolic compounds which protect the cells from ROS. 


\subsection{Acute toxicity}

Table 5 shows the result of the acute toxicity test of crude water extract of Momordica balsamina leaf given orally in rats. There was no death in Phases I and II of the experiment even at a concentration of $5000 \mathrm{mg} / \mathrm{kg}$. This agrees with the work of Kurami et al [32]. Hodge and Sterner toxicity scale states that $L_{50} \geq 5000 \mathrm{mg} / \mathrm{kg}$ body weight is practically non-toxic [33].

Table 5 Acute Toxicity Test of the Crude Water Extract of Momordica balsamina Administered Orally to Rats

\begin{tabular}{lllll}
\hline Phase & Group & No of Rats & Dose (mg/kg body wt) & No of Death \\
\hline 1 & A & 3 & 10 & $0 / 3$ \\
1 & B & 3 & 100 & $0 / 3$ \\
1 & C & 3 & 1000 & $0 / 3$ \\
2 & A & 3 & 1600 & $0 / 3$ \\
2 & B & 3 & 2900 & $0 / 3$ \\
2 & C & 3 & 5000 & $0 / 3$ \\
\hline
\end{tabular}

The toxicity profile and the therapeutic dose of a drug substance assist in the determination of effective dose of the drug substance. They aid in the determination of minimum and maximum non-lethal dose which provide information on effective dose or overdose. The result shows that M. balsamina is a safe herbal vegetable.

\section{Conclusion}

On the basis of the results of this study, the plant possesses nutritional and antioxidant properties, and is safe for consumption. It could be used in the management of some mal-nutritional problems and preventive health care.

\section{Compliance with ethical standards}

\section{Acknowledgments}

I would like to acknowledge the contributions of members of my Department, staff members of the Department of Pharmaceutical Microbiology and Biotechnology, Department Pharmaceutical Chemistry and Medicinal Chemistry, Department of Pharmacology working at the Animal House and the Department of Pharmacognosy and Traditional Medicine, Faculty of Pharmaceutical Sciences, University of Jos, for their immense assistance and contributions during the research work.

\section{Disclosure of conflict of interest}

No conflict of interest

\section{Statement of ethical approval}

The animal study was carried out after meeting the conditions of the Institutional Animal Care and Use (IACU) in collaboration with the Office of Laboratory Animal Welfare (OLAW) with the issuance of Ethical Clearance Certificate, Reference number: F 17 - 00379.

\section{References}

[1] Ekor M. (2014). The growing use of herbal medicine: issues relating to adverse reactions and challenges in monitoring safety. Frontiers in Pharmacology, 4 (177), 177.

[2] Yang W. (2014).Botanical, pharmacological, phytochemical, and toxicological aspects of antidiabetic plant Bidens pilosa L. Evidence-based Complimentary and Alternative Medicine, 1-14.

[3] Dalei J, Rao VM, Sahoo D, Rukmini M and Ray R. (2016). Review on the nutritional and pharmacological potencies of Moringaoleifera. European Journal of Pharmaceutical and Medical Research, 3(1), 150-155. 
[4] Kadiri O and Olawoye B. (2016).Vernonia amygdalina: an underutilized vegetable with nutriceutical potentialsa review. Turkish Journal of Agriculture- Food Science and Technology, 4(9), 763 - 768.

[5] Khaw K, Bingham S, Welch A, Luben R, Wareham N, Oakes S and Day N. (2001). Relation between plasma ascorbic acidand mortality in men and women in EPIC-Norfolk prospective study:a prospective population study. The Lancet, 357, 657-663.

[6] Thakur GS, Pandey M, Sharma R, Sanodiya BS, Prasad GBKS and Bisen PS. (2011). Factors affecting in vitro propagation of Momordica balsamina: a medicinal and nutritional climber. Physiology and Molecular Biology of Plants, 1(2), 193 - 197.

[7] Kaur I, Puri M, Ahmed Z, Blanchet FP, Mangeat B and Piguet V. (2013).Inhibition of HIV1 Replication by Balsamin, a Ribosome Inactivating Protein of Momordica balsamina .PLoS ONE, 8(9), 1 -9.

[8] Mshelia SH and Kurami Y. (2017). Anti-ulcerogenic effect of extracts of Momordica balsamina Linn against experimentally induced gastric ulceration in rats. International Journal of Medicinal plants Research, 6(4), 332 336.

[9] Akinyemi KO, Mendie UE, Smith ST, Oyelolu AO and Coker AO. (2005). Screening of some medicinal plants for anti-salmonella activity, Journal of Herbal Pharmacotherapy, 5(1), 45-60.

[10] Hassan LG and Umar K.J. (2006) Nutritional value of balsam apple leaves. Pakistan Journal Nutrition,5, 522-529.

[11] Jigam AA, Akanya HO and Adeyemi DJ. (2004).Antimicrobial and antiplasmodial effects of Momordica balsamina. Nigeria Journal of Natural Product Medicine, 8, 11-12.

[12] Kadiri JO, Okafor IS and Ogaji IJ. (2020). Effect of extraction solvents on the phytochemical constituents and antibacterial property of leaf extracts of Momordica balsamina Linn (Cucurbitaceae) found in North Central Nigeria. International Journal of Current Trends in Pharmaceutical Research, 8(1), 6 - 12.

[13] Ekeanyanwu C. (2013). Evaluation of crude protein and amino acid composition of Nigerian Mondora myristica (Ehuru).Parkistan Journal of Nutrition, 12(3), 219 - 223.

[14] Food and Agriculture Organisation (FAO) of the United Nations Rome (2003). Food energy- methods of analysis and conversion factors. FAO Food and Nutrition paper, 77

[15] Yust MM, Pedroche J, Girón-Calle J and Alaiz M. (2004). Determination of tryptophan by high performance liquid chromatographic detection. Food Chemistry, 85(2), 317 - 320.

[16] Brand-Williams W, Cuvelier ME and Berset C. (1995). Use of a free radical method to evaluate antioxidant activity. LWT- Food Science and Technology, 28 (1), 25 - 30.

[17] Deora SP, Mishra KC, Mavani P, Asha R, Shrivastava B and Rajesh NK. (2010). Effective alternative methods of LD50 help to save number of experimental animals. Journal of Chemical and Pharmaceutical Research, 2(6), 450 -453 .

[18] Parasuraman S. (2011).Toxicological screening.Journal of Pharmacology and Pharmacotherapy, 2(2), 74 - 79.

[19] Flyman MV and Afolayan A J. (2009). Proximate and mineral composition of the leaves of Momordica balsamina L: An underutilized wild vegetable in Botswana. International Journal of Food Science and Technology, 58(6), $419-423$.

[20] Pereira MA, O’Reilly E and Augustsson K. (2004). Dietary fibre and risk of coronary heart disease. A pooled analysis of cohort studies. Archnite Internal Medicine, 164 (4), 370 - 376.

[21] Galano A and Alvarez-Idaboy JR. (2011). Glutathione: Mechanism and kinetics of its non-enzymatic defense action against free radicals. Royal Society of Chemistry Advances, 1(9), 1763 - 1771.

[22] Kunle FO and Egharevba OH. (2013). Chemical Constituents and Biological activity of medicinal plants used for the Management of Sickle cell Disease - A review. Academic Journals, 7 (8), 3452-3476.

[23] Castiglioni S, Cazzaniga A, Albisetti W and Maier JAM. (2013). Magnesium and osteoporosis: current state of knowledge and future research directions. Nutrients, 5 (8), $3022-3033$.

[24] Perez V and Chang ET. (2014). Sodium - to - potassium ratio and blood pressure, hypertension, and related factors. Advances in Nutrition, 5, 712 - 741.

[25] Houston MC and Harper KJ. (2008). Potassium, magnesium and calcium: their role in both the cause and treatment of hypertension. The Journal of Clinical Hypertension, 10 (7), 2 - 11. 
[26] Koh ES, Kim SJ, Yoon HE, Chung JH, Chung S, Part CW and Shin SJ. (2014). Association of blood manganese level with diabetes and renal dysfunction: a cross-sectioned study of the Korean general population. BMC Endocrine Disorders, 14 (24), 1 - 8.

[27] Osredkar J and Sustar N. (2011). Copper and zinc, biological role and significance of copper/zinc imbalance. Journal of clinical Toxicology, 3 (1),1- 18.

[28] FitrianaWD,Ersam T,Shimizu K and Fatmawati S. (2016). Antioxidant activity of Moringa oleifera extracts. Indonesian Journal of Chemistry, 1 (3), 297 - 301.

[29] Jiang Z, Chen Y, Yoa F, Chen W, Zhong S, Zheng F and Shi G. (2013). Antioxidant, antibacterial and antischistosomal activities of extracts from Grateloupa livida (Harv) yamada. PLOS ONE, 2(1), 181 - 186.

[30] Michalak A. (2006). Phenolic compounds and their antioxidant activity in plants growing under heavy metal stress. Polish Journal of Environmental Studies, 15(4), 523 - 530.

[31] Sengul M, Yildiz H, Gungor N, Cetin B, Eser Z and Ercisli S. (2009). Total phenolic content, antioxidant and antimicrobial activities of some medicinal plants. Pakistan Journal of Pharmaceutical Sciences, 22(1), 102 - 106.

[32] Kurami Y, Onyeyili PO and Ogubuaja VO. (2006). Toxicity studies and effects of Momordica balsamina (Balsam apple) aqueous extract on serum electrolytes and plasma trace elements. Sahel Journal of Veterinary Sciences, 5 (1), $13-19$.

[33] Ahmed M. (2015). Acute toxicity (lethal dose 50 calculation of herbal drug somina in rats and mice), Pharmacology and Pharmacy, 6(3), 185 - 189.

\section{How to cite this article}

Kadiri JO, Okafor IS and Ogaji IJ. (2020). Safety and health benefits profile studies of leaf extracts of Momordica balsamina Linn (Cucurbitaceae) found in North Central Nigeria. GSC Biological and Pharmaceutical Sciences, 11(2), 278286. 